\title{
Student Primacy and the Post Pandemic University
}

\author{
Carl Senior ${ }^{1 *}$, Chris Howard ${ }^{2}$, Edward J. N. Stupple ${ }^{2}$ and Rowena Senior ${ }^{3}$ \\ ${ }^{1}$ School of Psychology, Aston University, Birmingham, United Kingdom, ${ }^{2}$ Department of Psychology, University of Derby, Derby, \\ United Kingdom, ${ }^{3}$ School of Education, University of Hertfordshire, Hatfield, United Kingdom
}

Keywords: undergraduates, students, HE, university, markets, learning, pandemic, decisions

\section{INTRODUCTION}

According to the noted economist, Joseph Schumpeter, a period of creative destruction ensures long standing market arrangements are destroyed and in doing so resources are freed up to drive innovation. The results of this period of change can be dramatic with the so called "dominant design"-the market entity that drives behaviour in a specific consumer space-facing a weakening of its dominant position, invariably contending with threats from competitors and ultimately being forced to change its business processes to survive in the market (Schubert, 2013). Many would argue that the Covid 19 pandemic has forced such a process on the global higher education sector. While the sector gradually returns to some semblance of normality it is an opportune time to take stock of traditional practices and reflect on whether they can exist to serve the new university after this period of creative destruction has ended (see e.g., Krishnamurthy, 2020; Benito et al., 2021).

Taking the above in hand focus must now turn to addressing a significant question: how can a university facilitate the primacy of the student to ensure that they are guided to make the right choice in joining a programme of study? In the traditional Higher Education (HE) sector, where the drive for marketisation is legion, this is a fairly complex question. However, the arrival of the pandemic landscape where the sector is likely to be faced with the unenviable task of making significant resource allocations in the context of so many unknown factors this question becomes Sisyphean in nature (Zhao and Watterston, 2021).

The full extent of the impact socially, politically and economically alongside the cost to human life is yet to unfold. Nonetheless, the HE sector and more generally everyday life has been severely impacted. Internationally, many Higher Education Institutions (HEIs) have moved to "remote" or "online" learning models where the campus has been "locked down" in wake of the spread of the virus and moved to the homes of students, academics and support staff. We are still in an age of uncertainty, and the move back to the campus with regular face-to-face teaching is unknown as the global sector is locked into strategies of social isolation and distancing. Whilst HEIs are in the process of navigating their way through the crisis, the impact on student engagement with higher learning has not received much focus.

University administrators must now answer a fundamental question. Do the traditional market principals and processes that have been much loved by sector managers carry as much value, if any, than they did in the pre-pandemic era? Furthermore what role, if any, does the undergraduate student play in this new and possibly very exciting environment? The United Kingdom HE sector has already seen student led protests calling for "no detriment" safeguards to protect grades and rent strikes on campus accommodation. This has put HEIs under increasing pressure to transform their current practices, but does this signal a move towards exposing the power of students as consumers 
in changing the higher education landscape or rather it merely identifies the established primacy of the student in the modern university (Jones et al., 2020)?

\section{STUDENT DECISION MAKING AND BEHAVIOURAL ECONOMIC THEORY}

This potential further shift is important when one considers that the often cited "graduate premium" (e.g., King and Ritchie, 2013) is likely to be of more value as graduates enter into the post pandemic workforce. Such a premium drives engagement with $\mathrm{HE}$ and this does indeed lead to a range of societal benefits (Mason et al., 2009). As such HE is often regarded as being a significant driver of a nation's development (Bloom et al., 2006), and is likely to form an essential part of the economic recovery plans following the pandemic. What lessons have university administrators learned from pre-pandemic business practices to ensure that the steady increase of undergraduate recruitment continues in the years to come?

With the increased information available to prospective students and the explicit framing of the HE sector as a marketplace where "value for money" is emphasised, the decision-making process is opened up to well established biases that have been explored by behavioural economists. Optimal decision-making necessarily occurs within a bounded rationality, whereby the decision-making process operates with limited resources, such that, time, motivation and cognitive limitations will all play a role in determining the choice that prospective students make (Moscati, 2021).

The behavioural economics literature is replete with such search models. Two of the most common search strategies that abound in the decision science literature are "satisficing" and "elimination by aspects" (e.g., Caplin et al., 2011). These are typical strategies that are employed when a decision needs to be simplified and likely to be used by individuals who may contemplate enrolling on a programme of higher study. Satisficing describes an approach where decisions are made on the basis of the "good enough" options that meet a minimum standard. Elimination-by-aspects instead takes a single factor and eliminates all options that do not satisfy those criteria. Both of these approaches can lead to suboptimal outcomes and mitigate against the goal of effective marketisation. Therefore, a desire to move away from the scenario where students choose universities based upon a small number of factors or rules of thumb is not, paradoxically, facilitated by an increase in relevant information. The proliferation of metrics is likely to increase rather than decrease the number of prospective students looking for their "cognitive escape hatch" to simplify the problem space they are faced with. These issues are further compounded when it is considered that many applicants will not know what constitutes a rational criteria for selecting an HEI and are likely to select a destination based upon an emotional connection to a location or a feeling of fitting in (e.g., Haywood and Molesworth, 2010). These issues are clearly significant for the university to survive in a potential crowded market place in post-Covid academia.

Here lies a fundamental paradox-the more information that a student is provided with the less they can use to make a clear and appropriate decision. It would seem that by placing the student at the centre of a heady maelstrom of various institutional and subject level league tables institutional administrators are in fact diluting the primacy of the undergraduate student.

There are further lessons to take from behavioral economics with regards to the extent of the options available to prospective students. Schwartz (2004) argued that excessive choice in colleges in the US has had deleterious consequences for the students therein. Individuals who are termed maximisers-those who seek the optimal choice and who are closest in their behavior to the economic-humans in market models are the most adversely effected. This is because the possibility of finding a course that is subjectively experienced as the optimal choice is far less likely when there are more options than can realistically be considered under the temporal and cognitive constraints students are operating under. Schwartz (2004) provides a wealth of examples from this literature on the "tyranny of choice" which show reduced satisfaction in economic decisions when there is greater choice, these include: increased feelings of missed opportunities; more feelings of stress, anxiety and unhappiness with the decision-making process; more regret regarding their choice; greater expectations of how good their chosen option should be and being more likely to choose no option at all. Furthermore, the unconditional offer that is often issued to students who are predicted to meet the entry requirement. The issuing of unconditional offers plays into a known cognitive bias for over-valuing things that are already in one's possession-the endowment effect (Morewedge, 2016). An applicant who has an unconditional offer is likely to place greater subjective value on that than on a conditional offer that may be a better fit for them. It is somewhat ironic that the marketisation project in $\mathrm{HE}$ could drive down student satisfaction through information overload and excessive choice.

\section{CONCLUDING POINTS}

Despite all of this, student recruitment and institutional marketization are in full swing. The acid test will be in the ability of HEIs to adapt and respond to the crisis in a bid to attract students. The current global crisis has changed the landscape for the foreseeable future and the legacy is unknown but there is little doubt that some HEIs will capitalize and flourish, and others will suffer catastrophic failure. The primacy of the student needs to be at the fore, which might involve a reworking of what choice looks like and what can be offered and by whom. It is likely that some HEIs will draw upon their status and history as capital, whereas others on their ability to adapt and provide effective teaching practices during the pandemic. Nonetheless, in keeping with our arguments throughout, the student cannot be merely reduced to an economic subject as a turn to the psychological impact of the global crisis is needed. Given the uncertainty the pandemic has brought to people's everyday lives, 
social isolation may lead to wider anxiety, depression and distress. HEIs are best to consider this as people are fundamentally social beings (Gergen, 2009). Recruitment strategies need to account for the psychological cost in terms of managing emotions and identity through the interactions they can provide and relationships within and between the student community and academics. The pandemic therefore presents an opportunity for change whereby the traditional top-down model of "student choice" with its bombardment of institutional information can be replaced by a bottom-up approach championing the "student voice" and acknowledging their lived experience. It is here,

\section{REFERENCES}

Benito, Á., Dogan Yenisey, K., Khanna, K., Masis, M. F., Monge, R. M., Tugtan, M. A., et al. (2021). Changes that Should Remain in Higher Education Post COVID-19: A Mixed-Methods Analysis of the Experiences at Three Universities. Higher Learn. Res. Commun. 11, 4. doi:10.18870/hlrc.v11i0.1195

Bloom, D. E., Canning, D., and Chan, K. (2006). Higher Education and Economic Development in Africa, Vol. 102. Washington, DC: World Bank.

Caplin, A., Dean, M., and Martin, D. (2011). Search and Satisficing. Am. Econ. Rev. 101 (7), 2899-2922. doi:10.1257/aer.101.7.2899

Gergen, K. J. (2009). Realities and Relationships: Soundings in Social Construction. Boston: Harvard University Press.

Haywood, H., and Molesworth, M. (2010). The Uncomfortable Mix of Seduction and Inexperience in Vocational Students' Decision Making. Mrkting Intell. \& Plan 28 (7), 831-846. doi:10.1108/02634501011086445

Jones, S., Vigurs, K., and Harris, D. (2020). Discursive Framings of Market-Based Education Policy and Their Negotiation by Students: the Case of 'value for Money' in English Universities. Oxford Rev. Educ. 46 (3), 375-392. doi:10.1080/ 03054985.2019.1708711

King, J., and Ritchie, C. (2013). The Benefits of Higher Education Participation for Individuals and Society: Key Findings and Reports: 'the Quadrants'. Research Paper for the Department for Business, Innovation and Skills (BIS). Available from : https://www.gov.uk/government/uploads/system/uploads/attachment_ data/file/254101/bis-13-1268-benefits-of-higher-education-participation-thequadrants.pdf (Accessed : 05 21, 2021).

Krishnamurthy, S. (2020). The Future of Business Education: A Commentary in the Shadow of the Covid-19 Pandemic. J. business Res. 117, 1-5. doi:10.1016/ j.jbusres.2020.05.034 student primacy takes centre stage by considering what students want from $\mathrm{HE}$, which would allow a dialogue between students, institutions and academics to emerge to drive the sector forward post-pandemic.

\section{AUTHOR CONTRIBUTIONS}

All authors listed have made a substantial, direct, and intellectual contribution to the work and approved it for publication.

Mason, G., Williams, G., and Cranmer, S. (2009). Employability Skills Initiatives in Higher Education: what Effects Do They Have on Graduate Labour Market Outcomes? Edu. Econ. 17 (1), 1-30. doi:10.1080/09645290802028315

Morewedge, C. K. (2016). Why Buyers and Sellers Inherently Disagree on what Things Are worth. Harvard Business Review. Available at : https://hbr.org/ 2016/05/why-buyers-and-sellers-inherently-disagree-on-what-things-are-worth (Accessed : 05 21, 2021).

Moscati, I. (2021). On the Recent Philosophy of Decision Theory. J. Econ. Methodol. 28 (2), 1-9. doi:10.1080/1350178x.2020.1868777

Schubert, C. (2013). How to Evaluate Creative Destruction: Reconstructing Schumpeter's Approach. Cambridge J. Econ. 37 (2), 227-250. doi:10.1093/ cje/bes055

Schwartz, B. (2004). The Tyranny of Choice. Sci. Am. 290 (4), 70-75. doi:10.1038/ scientificamerican0404-70

Zhao, Y., and Watterston, J. (2021). The Changes We Need: Education post COVID-19. J. Educ. Change 22 (1), 3-12. doi:10.1007/s10833-021-09417-3

Conflict of Interest: The authors declare that the research was conducted in the absence of any commercial or financial relationships that could be construed as a potential conflict of interest.

Copyright (C) 2021 Senior, Howard, Stupple and Senior. This is an open-access article distributed under the terms of the Creative Commons Attribution License (CC BY). The use, distribution or reproduction in other forums is permitted, provided the original author(s) and the copyright owner(s) are credited and that the original publication in this journal is cited, in accordance with accepted academic practice. No use, distribution or reproduction is permitted which does not comply with these terms. 